\title{
Correction to: (Anti-)estrogenic and (anti-)androgenic effects in wastewater during advanced treatment: comparison of three in vitro bioassays
}

\author{
Linda Gehrmann ${ }^{1} \cdot$ Helena Bielak ${ }^{2} \cdot$ Maximilian Behr $^{3} \cdot$ Fabian Itzel $^{1} \cdot$ Sven Lyko $^{4} \cdot$ Anne Simon $^{2} \cdot$ Gotthard Kunze $^{5}$. \\ Elke Dopp ${ }^{2,6} \cdot$ Martin Wagner ${ }^{3} \cdot$ Jochen Tuerk ${ }^{1,6}$
}

Published online: 26 April 2019

(C) Springer-Verlag GmbH Germany, part of Springer Nature 2019

Correction to: Environmental Science and Pollution Research (2018) 25:4094-4104 https://doi.org/10.1007/s11356-016-7165-4

Linda Gehrmann and Helena Bielak contributed equally to this work and are regarded as joint first authors.

Publisher's note Springer Nature remains neutral with regard to jurisdictional claims in published maps and institutional affiliations.

The online version of the original article can be found at https://doi.org/ 10.1007/s11356-016-7165-4

Jochen Tuerk tuerk@iuta.de

1 Institut für Energie- und Umwelttechnik e. V. (IUTA, Institute of Energy and Environmental Technology), Bliersheimer Str. 58-60, 47229 Duisburg, Germany

2 IWW Rheinisch-Westfälisches Institut für Wasserforschung gemeinnützige GmbH, Moritzstr. 26, 45476 Muelheim an der Ruhr, Germany

3 Abteilung Aquatic Ecotoxicology, Goethe University Frankfurt, Max-von-Laue-Str. 13, 60438 Frankfurt am Main, Germany

4 Emschergenossenschaft/Lippeverband (EG/LV), Kronprinzenstraße, 24, 45128 Essen, Germany

5 Leibniz Institute of Plant Genetics and Crop Plant Research (IPK), OT Gatersleben, Corrensstr. 3, 06466 Stadt Seeland, Germany

6 Centre for Water and Environmental Research (ZWU), University Duisburg-Essen, Universitätsstr. 2, 45117 Essen, Germany 